\title{
Editorial
}

\section{Canadian medicare: historical reflections, future directions}

\author{
COLLEEN M. FLOOD* \\ Professor, University Research Chair and Director, Centre for Health Law Policy \& Ethics, University of Ottawa, \\ Ottawa, ON, Canada \\ GREG MARCHILDON \\ Professor \& Ontario Research Chair in Health Policy \& Systems Design, University of Toronto, Toronto, ON, Canada \\ GAIL PAECH \\ Chief Executive Officer of Associated Medical Services, Toronto, ON, Canada
}

This special volume is a reflection by scholars from across Canada and around the world on Canadian medicare. Our goal was to marry history (and historical scholars) with policy (and policy scholars) to reflect on how history can help us better understand present policy problems in Canadian medicare. Many readers will be familiar with Winston Churchill's adage that 'those who fail to learn from history are doomed to repeat it'. Philosophers, writers, thinkers and academics have opined for centuries on the need for a fulsome understanding of history. Churchill also feared that erasing the past would lead to 'the most thoughtless of ages. Every day headlines and short views'(National Churchill Museum, 2012). In other words, blindness to the past hinders innovation and progress and propagates, at best, an inadequate status quo.

This special edition of the Journal of Health Economics Policy \& Law has been supported by Associated Medical Services (AMS), which, for more than 40 years, has advanced the assessment and use of knowledge, especially historical knowledge, to understand and improve health care in Canada. AMS' (2017) first priority upon becoming a charity in 1976 was to support scholarly work in the history of medicine. AMS (2017) created five History of Medicine Chairs in the 1970s and, in 2015, introduced the History of Medicine and Healthcare Post-Doctoral Fellowship and the Hannah Chair in the History of Aboriginal Health at the Northern Ontario School of Medicine. In celebration of its 80th anniversary, AMS hosted a conference in Toronto in May 2017 that focused on

*Correspondence to: Colleen M. Flood, Professor, University Research Chair \& Director, Centre for Health Law Policy \& Ethics, University of Ottawa, Ottawa, ON, Canada. Email: colleen.flood@uottawa.ca 
what can be learned from history to address present-day policy challenges in Canada's health care system. In total, 14 history and policy thought leaders shared their knowledge on how to solve present and future challenges in Canadian medicare, and exchanged ideas with over 100 conference participants. This special edition reflects the substantial body of knowledge and ideas generated by this event.

We begin with a brief history of Canadian universal health care, to help the reader better understand the policy challenges this volume wrestled with by fusing historical and policy perspectives. Canada was more gradual in establishing universal health coverage nationally, as compared, for example, to countries like the United Kingdom, the Netherlands and New Zealand. In 1947, the province of Saskatchewan implemented the first universal hospital insurance plan in North America spearheaded by Premier Tommy Douglas and his social democratic party, the Co-Operative Commonwealth Federation. The success of this and other provincial hospital insurance plans laid the groundwork for the Hospital Insurance and Diagnostic Services Act ${ }^{1}$ passed by the Parliament of Canada in 1957, which established universal public coverage for hospital care across the country. In the early 1960s, Douglas successfully campaigned for re-election in Saskatchewan on the promise of expanding health coverage to include physician services. When the Saskatchewan Medical Care Insurance Act ${ }^{2}$ came into force 1 July 1962, it sparked a backlash from physicians and a fierce anti-medicare campaign throughout Canada. Eventually, other provinces emulated Saskatchewan after the federal Liberal government - with the support of Douglas' New Democratic Party - offered to share the cost of financing with provincial governments through the Medical Care Act in 1966. ${ }^{3}$ In 1984, a subsequent Liberal government passed the Canada Health Act (CHA) which merged the '57 and '66 laws with new measures to limit extra-billing and user charges, which had become a concern by this time. ${ }^{4}$

Although the Canadian system has evolved over time, two essential characteristics have remained constant since 1984:

Disaggregated federalism: by comparison other national health care systems, the Canadian 'system' is extremely disaggregated due to the federal division of powers (and its interpretation by the courts), which assigns most of the constitutional responsibility for health care to the provinces (Flood et al., 2017).

The federal government has nevertheless established a role for itself legislatively, setting out criteria in the CHA to be met by the 10 Canadian provinces and three territories if they wish receive a federal contribution to their provincial insurance plans.Bans on two-tier care: the CHA prohibits extra-billing and user

1 S.C. 1957, c. 28.

2 R.S.S. 1965 , c. 255 , s. 1.

3 S.C. $1966-67$, c. 64

4 CHA, R.S.C., 1985 , c. C-6. 
charges. In response, provincial governments have further legislated measures to tamp down prospects for private care. This sets Canada apart from other nations that are more permissive in allowing individuals to use private finance to cover services that are also insured by the public or social health insurance scheme.

The Canadian system of universal health coverage is showing its age. Although medicare provides 'deep' coverage for hospital and physician services, it does not include within its protections - nor fund federally - prescription drugs and medical devices needed outside of hospital walls, home care, dental care and so on. Left to their own devices, Canada's provinces tend to fall into a more US-style of provision for non-medicare services, offering coverage for the elderly and poor in response to inadequate coverage through employer-based private health insurance. Gaps in coverage persist, and have significant consequences for Canadians' health. For example, a 2012 study found that roughly 5000 deaths and up to 2700 heart attacks and strokes could have been prevented among younger and middleaged diabetes patients in Ontario, over the six-year period studied, if the province had a universal drug plan and these individuals were able to access insulin and other needed medications (Booth et al., 2012).

Growing wait times and gaps in access are causing Canadians to question their system. Some $15 \%$ of Canadians lack the basic security of a family physician (Health Fact Sheets, 2015). A recent Commonwealth Fund study ranked Canada near the bottom of developed countries with respect to accessibility - behind the US health care system - on some important indicators: half of Canadians surveyed reported waiting more than two hours for emergency room care, compared to $25 \%$ of Americans. Some $30 \%$ of Canadians said they waited two or more months to see a specialist, compared to 6\% of Americans (Schneider et al., 2017). Whilst poll after poll finds strong public support for care allocated on the basis of need rather than ability to pay, Canadians' faith in medicare has been sorely tested by long wait times and growing gaps in access to family care and specialists, important medications and long-term care. IPSOS Reid (2003-2010) reports that between 2003 and 2010, Canadian attitudes on the quality of health care services have shifted markedly from positive to negative. The lackluster performance of the Canadian system may lead to the mistaken conclusion that the basic values underlying medicare are outdated or quixotic. If the core values of access on the basis of care rather than ability to pay are to survive, it is imperative to embrace evidence-based reform that is also grounded in history to better understand the windows of opportunity for change.

In addition to learning from history, we reflected on the performance of Canada relative to other countries to help us think through improvements to Canadian medicare. As you will see in this volume, we asked a number of authors from the United Kingdom to contribute their perspectives given that, in recent Commonwealth Fund studies, the United Kingdom tops the list of 11 developed 
countries in overall performance on issues like quality, accessibility efficiency (Schneider et al., 2017). We also invited contributors from Australia, Israel and the United States. What was interesting were the concerns and criticisms levied by these authors about their own systems, which perhaps indicates the limitations of the Commonwealth Fund studies and the fact that every health system has weaknesses that need to be addressed.

Although the reader may glean his or her own lessons from this set of articles, we provide our analysis of the lessons for Canadian policy-makers from this historical reflection.

i. Federal vs provincial leadership: historically, Canadians have had a tendency to look to the federal government for national leadership on health care reform. The common mythology seems to be that the best results are achieved through central government leadership (e.g. the growing momentum for pharmacare in Canada is primarily targeted at the federal government). However, history teaches us that, from its inception, Canadian medicare emerged from provincial leadership which was supplemented only later by federal leadership. The persistence and ultimate success of Saskatchewan, in particular, was a driving force behind the federal government's adoption of universal health coverage. The realities of federalism, legalism and history point to the fact that perhaps instead of wrestling the federal government into establishing universal pharmacare, for example, long and lasting reform may best be achieved by first advancing in one province. Through such provincial experimentation, a body of evidence can be generated, all the while furthering political discourse, catalyzing public support, and ultimately contributing to reform. It may well be, as Marchildon (2018) describes in this volume, that those seeking 'big bang reform' seek to break from the past in order to end a path dependency supported by institutions that have evolved over time. Understanding this past does not imply a support of status quo institutions. Indeed, a careful reading of history informs the ways in which major reform has been achieved despite past policy path dependencies and the opposition of numerous organizations that have a strong interest in maintaining the status quo.

ii. Accountability: division of powers between levels of government has too frequently resulted in a loss of accountability for the Canadian health care system and continuous finger pointing as to who is to blame For example, provinces attribute long wait times to lack of federal funding while the federal government blames provincial mismanagement. Nowhere, as Lavoie (2018) explains in this volume, is this better exemplified than with respect to Indigenous peoples' health. Federal and Provincial governments have attempted to shift responsibility between each other for the appalling health outcomes experienced by many Indigenous peoples. Efforts to devolve funding and power from both federal and provincial governments to Indigenous peoples may offer the best hope for amelioration.

iii. Incrementalism: although one might hope for provincial leadership, for example, on universal pharmacare, the politics of incrementalism impede substantive progress. As with the United States - in response to concerns 
regarding access for morally deserving groups such as the elderly and the poor - provinces have introduced incremental improvements to insurance programs. The most recent example of this is the Ontario provincial government now extending prescription drug insurance to all those under the age of 25 . Complaining about such piecemeal solutions can simply reinforce existing institutions and interest groups who support the status quo and oppose more effective efforts to improve access. In part, they may believe that their remuneration, revenue stream or autonomy might be negatively affected. In this sense, universal pharmacare poses a potential threat to the pharmaceutical industry and private insurance carriers in Canada. Both sectors have, for decades, urged the federal and provincial governments to take an incremental approach to reform.

iv. Physician control: one of the defining historical features of the Canadian system is the level of control exercised by physicians, with some complaining that the system is organized for their convenience rather than in the best interests of Canadians. For their part, physicians continue to defend a historic compact that was forged at the conclusion of the 23-day Doctors' Strike in Saskatchewan in 1962, which to this day remains the template for physicians' relationship to medicare. The Saskatoon Agreement stipulated that while provincial governments could establish a single-payer mechanism as part of universal health coverage, doctors would continue to be independent of governments, operating as contractors paid on a fee-for-service basis (Marchildon and Schrijvers, 2011). In addition, provincial medical associations would negotiate directly with provincial ministers of health and their departments on remuneration and working conditions. With the introduction of regional and provincial health authorities in Canada, doctors' accountability to the health system was delinked further: organized medicine rejected any contractual relationship between doctors and the organizations established to manage and coordinate facilities and services within defined geographic boundaries (Marchildon, 2016). Attempts have been made to involve physician leaders as change agents but unless and until both responsibility and funding are devolved to de-politicized agencies (as is the case, e.g. in the United Kingdom), it seems likely that the political power of physicians in negotiations with governments, highly attuned to their own political fortunes, will result in perpetuation of the status quo.

v. Court challenges: tensions are emerging between Canadian medicare and the Canadian Charter of Rights and Freedoms, which guarantees certain rights (e.g. in s. 7 the right to 'life, liberty and security of the person' and in s. 15, the right to equal treatment under the law). Laws and policies that infringe such rights risk being overturned by the courts, unless government lawyers can justify them under a proportionality analysis. While the Supreme Court of Canada has to date been reluctant to find a 'positive' right to adequate public health care (i.e. a right not to have to unduly wait for care), it has recognized 'negative' rights in this area: rights to purchase care privately without undue state interference. In Chaoulliv. Quebec, the Court ruled that, where patients' health is jeopardized by long wait times in medicare, the law must allow patients the safety valve of 
parallel private insurance. ${ }^{5}$ Building on this case, proponents of privatization have turned their attention to various other laws inhibiting privately financed care. A case that went to trial in September 2016 will test the constitutionality of the province of British Columbia's medicare laws, inspired by the $\mathrm{CHA}$, that ban extra-billing and bar physicians who participate in medicare from moonlighting in private practice. That Charter rights could be used to undermine medicare is a grave rebuke to the assumption, common among advocates of human rights and dignity, that rights litigation is a positive, progressive force. As Flood and Thomas (2018) discuss in this volume, these Charter challenges will serve either as a wakeup call or death knell for medicare; everything depends on how Canadian governments respond. The courts can permit privatization to undercut equity and access, or they can respond creatively with new legal and policy solutions to improve equity and access, defending the human rights and dignity of all. If there is a 'silver lining' to these constitutional challenges, it lies in Canada's rich tradition of dialogue between the courts and governments. If governments are to be well prepared for this dialogue, a national conversation is urgently needed on how governments should reply, in the event that the courts push the country further toward a two-tier health care system under the Chaoulli precedent.

vi. Growing income inequality will further challenge solidarity: pressures on medicare will be further exacerbated by Canada's growing wealth inequality: the share of earned income held by the top $1 \%$ of Canadians has doubled since the late 1970s, from 8 to 16\% (Mark and Isabelle, 2018). In this volume, Mark Stabile and Maripier Isabelle demonstrate a correlation between growing inequality and increased levels of private health finance across Organization for Economic Co-Operation and Development countries, hypothesizing that median voters in increasingly non-egalitarian societies are not satisfied by the offerings of universal health care systems. Absent major reforms to meet public expectations of timeliness, quality and accessibility, universal health care will succumb, bit by bit, to the demands for of piecemeal privatization.

Where historians can provide informed context and insight to the catalysts behind successful reforms of the past (Marchildon, 2018: 1), naivety toward history, whether intentional or not, can create a cycle of opportunity costs. Many of the challenges facing Canadian medicare have been understood for generations. For example, the architects of medicare stressed, in the early 1960s the importance of establishing a universal pharmacare scheme, and yet so little has been accomplished in the intervening half century. It is worth reflecting on what future historians will have to say about our efforts at protecting and improving medicare. If demographic trends persist, the country will over the coming decades find itself struggling to care for an aging population, amidst growing demands for costly new drugs and health technologies. Inaction or neglect during times of stability

5 The majority did only rule with respect to the Quebec Charter: with respect to the Canadian charter there was no definitive conclusion at this time as three judges ruled there was a breach of s. 7 , whereas another three found no such breach - see Colleen et al. (2005). 
force us to react as opposed to steadily build momentum that is designed to give way to meaningful reform. And yet, these patterns have recurred throughout history. Revolutions that concentrate all too much power in the hands of elites have been seen to produce ruthless dictatorships. Periods of national debt have been addressed by severe slashing of public budgets only to later require urgent and ill-planned investment. And the continued systematic exclusion of Canada's Indigenous peoples from federal-provincial-territorial health system negotiations continues to further inequities and raise health care costs (Lavoie, 2018: 3). In the words of Gustave Flaubert, 'Our ignorance of history causes us to slander our own times'.

\section{References}

Associated Medical Services (AMS) (2017), History of medicine and healthcare, http://www. ams-inc.on.ca/history-of-medicine-and-healthcare/.

Booth, G., et al. (2012), 'Universal drug coverage and socioeconomic disparities in major diabetes outcomes', Diabetes Care, 35(11): 2257-2264.

Flood, C. M., S. Lorne and R. Kent (eds) (2005), Access to Justice, Access to Care: The Legal Debate Over Private Health Insurance, Toronto, ON: University of Toronto Press.

Flood, C. M., W. Lahey and B. Thomas (2017), 'Federalism and Health Care in Canada: A Troubled Romance', in P. Oliver, P. Macklem and N. Des Rosiers (eds), The Oxford Handbook of the Canadian Constitution, New York: OUP.

Flood, C. M. and B. Thomas (2018), 'A successful Charter challenge to medicare?: Policy options for Canadian provincial governments', Health Economics, Policy and Law, 13 (3-4): 433-449.

Health Fact Sheets (2015), 'Access to a regular medical doctor, 2014'. Ottawa, ON: Statistics Canada; Cat No. 82-625-X, www.statcan.gc.ca/pub/82-625-x/2015001/article/14177eng.htm.

National Churchill Museum (2012), 'Those who fail to learn from history ...', House of Commons, 16 November 1948, https://www.nationalchurchillmuseum.org/blog.html.

IPSOS Reid (2003-2010), 'Annual National Report Card on Health Care'. Ottawa, ON: Canadian Medical Association, www.ipsos-na.com.

Lavoie, J. G. (2018), 'Medicare and the care of First Nations, Métis and Inuit', Health Economics, Policy and Law, 13(3-4): 280-298.

Marchildon, G. P. (2016), 'Regionalization: what have we learned?', Healthcare Papers, 16(1): 8-14.

Marchildon, G. P. (2018), 'Can history improve Big Bang health reform? Commentary', Health Economics, Policy and Law, 13(3-4): 251-262.

Marchildon, G. P. and K. Schrijvers (2011), 'Physician resistance and the forging of public health care in Canada and Belgium in the 1960s', Medical History, 55(2): 203-222.

Mark S. \& Isabelle M., (2018), 'Rising inequality and the implications for the future of private insurance in Canada', Health Economics, Policy and Law, 13(3-4): 406-432.

Schneider, E. C., D. O. Sarnak, D. Squires, A. Shah and M. M. Doty (2017), 'Mirror, Mirror: How the U.S. Health Care System Compares Internationally at a Time of Radical Change', The Commonwealth Fund, July. 